\title{
Sociodemographic, Clinical and Quality of Life Aspects of People Aged over 50 Years Living with HIV/AIDS
}

\author{
Alexsandra Rodrigues Feijão1, Klebia Karoline dos Santos Neco1, \\ Jéssica Dayane Dantas Costa ${ }^{2}$, Isabelle Christine Marinho de Oliveira1, \\ Ana Luisa Brandão de Carvalho Lira1, Bertha Cruz Enders ${ }^{1}$ \\ ${ }^{1}$ Nursing Department, Federal University of Rio Grande do Norte, Natal, Brazil \\ ${ }^{2}$ Multicampi School of Medical Sciences, Federal University of Rio Grande do Norte, Natal, Brazil \\ Email: alexsandrarf@hotmail.com
}

Received 13 April 2016; accepted 6 June 2016; published 9 June 2016

Copyright (C) 2016 by authors and Scientific Research Publishing Inc.

This work is licensed under the Creative Commons Attribution International License (CC BY). http://creativecommons.org/licenses/by/4.0/

(c) (i) Open Access

\begin{abstract}
Introduction: In the last few years, there has been a growth in the number of cases of people with HIV/AIDS aged 50 years and older. This is explained by the inclusion of antiretroviral therapy, increased survival of patients as well as by the growth in the number of infected people in this age group. Objective: To analyze the association between sociodemographic and clinical characteristics with the QOL of people aged 50 years or older living with HIV/AIDS. Methods: Quantitative, cross-sectional study conducted in the outpatient clinic of a reference hospital in Natal, Brazil. The sample consisted of 50 subjects, aged over 50 , seropositive for HIV and with cognitive conditions to answer the interview. Authors used sociodemographic and clinical evaluation tools and the WHOQOL-HIV BREF scale. Results: Sociodemographic: respondents' average age was $\mathbf{5 7 . 3 2}$ years, $58 \%$ male, $38 \%$ brown, $26 \%$ incomplete primary education, $46 \%$ single, $56 \%$ retired, $70 \%$ with a monthly income of 1 to 2 minimum wages and $70 \%$ Catholic. Clinical: $60 \%$ have a partner without the diagnosis of HIV/AIDS; $62 \%$ had not been hospitalized previously; $66 \%$ did not have opportunistic infections; $40 \%$ indicated that there was a change in the physiological sexual function after the onset of the disease. Quality of life: people living with HIV/AIDS had low scores in QOL domains. When associating sociodemographic and clinical aspects, it was observed that they had associations with QOL, especially in regard to education, income, religion, change in sexual function and feelings. Conclusion: The spiritual domain was highlighted with the best performance, collaborating to facing, hope and resilience of HIV/AIDS.
\end{abstract}

\section{Keywords}

AIDS, Quality of Life, Aging

How to cite this paper: Feijão, A.R., dos Santos Neco, K.K., Costa, J.D.D., de Oliveira, I.C.M., de Carvalho Lira, A.L.B. and Enders, B.C. (2016) Sociodemographic, Clinical and Quality of Life Aspects of People Aged over 50 Years Living with HIV/AIDS. Open Journal of Nursing, 6, 435-442. http://dx.doi.org/10.4236/ojn.2016.66045 


\section{Introduction}

In recent years, population aging has been changing the global epidemiological picture. Reflecting the increased life expectancy and decreased fertility and mortality rates, there has been a considerable growth in the index of communicable and non-communicable diseases, which are major causes of morbidity and mortality and disabilities [1] [2].

HIV/AIDS, a transmissible chronic disease, has been growing rapidly in this population, becoming a major public health problem. According to the Joint United Nations Programme on HIV/AIDS (UNAIDS) and the World Health Organization (WHO), approximately 4.2 million of the 35 million people living with HIV/AIDS (PLWHA) worldwide are aged 50 years or older [3].

In Brazil, this number reaches 56,377 cases of AIDS in people over 50 years of age, which represents $7.45 \%$ of the total of 757,042 people diagnosed between 1980 and 2014. This percentage may seem insignificant; however, when comparing the detection rates between the years 2002 and 2013, we can see a significant increase of cases in people aged from 50 to 54 years, which increased from 26.3 to 28.9/100,000 inhabitants. The Northeast Region is the third region with the highest number of cases, accounting for $14.3 \%$ of diagnoses reported in the country [4].

This growth can be explained by the involvement of people over 50 years old in risk activities, associated with the provision of drugs for erectile dysfunction, as well as the lack of integration of the elderly people in services and methods to combat HIV [1]-[3]. Adherence to antiretroviral therapy (ART) also explains the increased survival of HIV-positive people due to the decreased viral load and increased CD4 lymphocytes, reducing the appearance of opportunistic diseases and disease progression [5]-[7].

Nevertheless, the increased survival does not necessarily mean that there was aging with quality of life. Given the complexity of this concept, the WHO defines quality of life (QOL) as “an individual's perception of their position in life in the context of the culture and values systems in which they live and in relation to their goals, expectations, standards and concerns”. As a broad concept, QOL comprises physical, psychological and social health and beliefs towards the environment [8].

In order to improve the QOL as people get older, the WHO established in 2002 the document “Active ageing: a policy framework", which addresses the aging process in an active manner, allowing people to participate continually in social, economic, spiritual and civil issues, safely and with the necessary care to maintain their health. By exposing HIV/AIDS, this policy shows a deficient collection of data and information related to education, prevention and treatment of the disease, as well as on the impact of programs for older people with HIV/AIDS [2].

The disease monitoring conditions suggest that the QOL of these individuals may be affected. Furthermore, studies investigating the relationship between the sociodemographic characteristics of people with HIV and their QOL have focused in young individuals and have different results [9] [10]. Adults over 50 years of age reported weak association with age [11]. Therefore, this demonstrates the need to focus studies in this age group, with a view to detecting possible areas of action to reduce the risk of disease progression and impact on the treatment process.

\section{Objective}

This study aims to analyze the association between sociodemographic and clinical characteristics with the QOL of people aged 50 years or more living with HIV/AIDS.

\section{Material and Methods}

This is a quantitative, cross-sectional study developed in the HIV/AIDS outpatient clinic of Giselda Trigueiro Hospital, a reference hospital in the monitoring and treatment of infectious diseases in the state of Rio Grande do Norte (RN), Brazil.

For the sample definition, authors used the number of cases reported in the Disease Information System of RN in 2012, totaling 77 cases of HIV in people over 50 years old [12]. It is worth mentioning that the data for the year 2013 were not used to estimate the sample, as they were not available in the system.

For the sample, authors elected patients aged over 50 years, seropositive for HIV, who were being monitored at that clinic and in cognitive conditions to answer the interview. Exclusion criteria were: patients deprived of freedom, because this condition may interfere with the perception of QOL. 
Sampling was done by convenience, consecutively to patients' attendance in the service for consultations. For the interviews, researchers initially verified the schedule of consultations, seeking to identify patients who were part of the inclusion criteria. After these procedures, 50 subjects were included in the sample. When attending the clinic for the service, users were approached and invited to participate in the research.

Data collection occurred from December 2013 to January 2014. The questionnaires were administered by nursing graduate students previously trained and qualified to conduct the interview.

Sociodemographic and clinical evaluation tools and the WHOQOL-HIV BREF scale were used. The first tool relates to the sociodemographic and clinical questionnaire that includes variables such as age, sex, race, education, marital status, occupation, income, religion, partner with HIV/AIDS, previous hospitalization, opportunistic diseases, changes in sexual function and feelings. The second instrument is the scale of assessment of QOL called WHOQOL-HIV BREF. The full Brazilian version has 120 questions [13]; however, the version that assesses the general quality of life of people living with HIV/AIDS consists of 31 items measuring quality of life and overall health, distributed in 6 domains (physical, psychological, level of independence, social relationships, environment and spirituality/religion/personal beliefs), with answers on that experienced in the last two weeks. Questions are individually scored on a Likert 5-point scale, in which 1 (none), 2 (very little), 3 (more or less), 4 (enough) to 5 (extremely). Therefore, the variation in score indicates low and negative perceptions to high and positive perceptions.

For the organization of information and analysis of the data, it was initially built a database in Excel format, version 2010. Then, the free software R, version 3.0.0, was used to carry out the descriptive tables and applications of statistical tests. Before, it was verified that the data in the study had normal distribution (using the Shapiro Wilks test), a necessary precondition for the application of average comparison parametric tests (ANOVA). If the data normality assumption was not met, the nonparametric Mann-Whitney or Kruskal-Wallis test was still applied. Statistically significant correlations were considered with $p \leq 0.05$.

\section{Results}

Results are presented in the form of tables and relate to the sociodemographic and clinical characteristics to the scores of the QOL domains according to the WHOQOL-HIV BREF.

Of the 50 patients interviewed, the average age was 57.32 years ( $S D \pm 5.20$ ), with minimum of 50 years old and maximum of 72 years old. $58 \%$ were male, $62 \%$ brown, $26 \%$ had incomplete primary education, $46 \%$ were single, $56 \%$ retired, $70 \%$ had wage income of approximately between one and two minimum wages (MW), and $70 \%$ stated being Catholic. Regarding clinical situations of illness, $60 \%$ of respondents reported that partners do not have a diagnosis of HIV/AIDS, $62 \%$ had never been hospitalized earlier due to the disease, $66 \%$ have never presented opportunistic disease and $60 \%$ stated that no changes in sexual and physiological functions have appeared after the onset of disease.

Table 1 shows the sociodemographic and clinical characteristics presented in this study.

Regarding quality of life, Table 2 shows the scores of QOL domains from the WHOQOL-HIV BREF, according to sociodemographic and clinical variables. Especially the spiritual domain had higher average and better QOL performance.

Among the sociodemographic and clinical aspects with implications for the QOL, there is highlight for education, income, religion, change in sexual function and positive and negative feelings. Thus, the domains physical, psychological, level of independence, social relationships, and spirituality/religion/personal beliefs are determinants to influence the QOL of people aged 50 years or more.

\section{Discussion}

In general, the sociodemographic and clinical profile of the sample is similar to that observed in adult patients with HIV/AIDS in Brazil and in other countries: sample with majority of males, with low income, low education, and low frequency of concomitant diseases to HIV and hospitalizations [9] [14].

Regarding the physical domain of WHOQOL-HIV BREF, there was positive evidence of correlation with the variable religion and negative correlation with the feelings anger and fear. With regard to religion, studies indicate that it helps in reducing the negative feelings and maintaining hope, which helps coping with the disease and improves adherence to treatment [15], contributing to coping and living with the diagnosis of HIV/AIDS, through feelings of hope, resilience and healing [16]. 
Table 1. Sociodemographic and clinical characteristics of adults aged 50 years or more with HIV/AIDS treated at the outpatient clinic.

\begin{tabular}{|c|c|c|c|}
\hline \multicolumn{2}{|c|}{ Sociodemographic and clinical characteristics } & \multirow{2}{*}{$\begin{array}{c}\mathbf{n} \\
29\end{array}$} & \multirow{2}{*}{\begin{tabular}{|l}
$\%$ \\
58
\end{tabular}} \\
\hline Gender & Male & & \\
\hline & Female & 21 & 42 \\
\hline \multirow[t]{3}{*}{ Race } & White & 17 & 34 \\
\hline & Brown & 31 & 62 \\
\hline & Black & 2 & 4 \\
\hline \multirow[t]{5}{*}{ Education } & Incomplete primary education & 13 & 26 \\
\hline & Complete primary education & 12 & 24 \\
\hline & Incomplete high school & 7 & 14 \\
\hline & Complete high school & 12 & 24 \\
\hline & Higher education & 6 & 12 \\
\hline \multirow[t]{4}{*}{ Marital status } & Single & 23 & 46 \\
\hline & Married & 10 & 20 \\
\hline & Widow(er) & 10 & 20 \\
\hline & Other & 7 & 14 \\
\hline \multirow[t]{4}{*}{ Occupation } & Working & 9 & 18 \\
\hline & Retired & 28 & 56 \\
\hline & Freelance & 7 & 14 \\
\hline & Unemployed & 6 & 12 \\
\hline \multirow[t]{3}{*}{ Family income } & $\leq 1 \mathrm{MW}^{*}$ & 9 & 18 \\
\hline & 1 - $2 \mathrm{MW}$ & 35 & 70 \\
\hline & $>2 \mathrm{MW}$ & 6 & 12 \\
\hline \multirow[t]{5}{*}{ Religion } & Catholic & 35 & 70 \\
\hline & Protestant & 7 & 14 \\
\hline & Spiritualist & 2 & 4 \\
\hline & Other religion & 5 & 10 \\
\hline & Without religion & 1 & 2 \\
\hline \multirow[t]{3}{*}{ Partner with HIV/AIDS } & Yes & 13 & 26 \\
\hline & No & 30 & 60 \\
\hline & No partner & 7 & 14 \\
\hline \multirow[t]{2}{*}{ Previous hospitalization } & Yes & 19 & 38 \\
\hline & No & 31 & 62 \\
\hline \multirow[t]{2}{*}{ Opportunistic diseases } & Yes & 17 & 34 \\
\hline & No & 33 & 66 \\
\hline \multirow[t]{2}{*}{ Change in sexual function } & Yes & 20 & 40 \\
\hline & No & 30 & 60 \\
\hline \multirow[t]{6}{*}{ Feelings } & Fear & 4 & 8 \\
\hline & Anxiety & 4 & 8 \\
\hline & Sadness & 11 & 22 \\
\hline & Anger & 2 & 4 \\
\hline & Joy & 14 & 28 \\
\hline & Safety & 7 & 14 \\
\hline
\end{tabular}

MW $=$ Minimum Wage. 
Table 2. Distribution of scores of WHOQOL-HIV BREF according to sociodemographic and clinical variables.

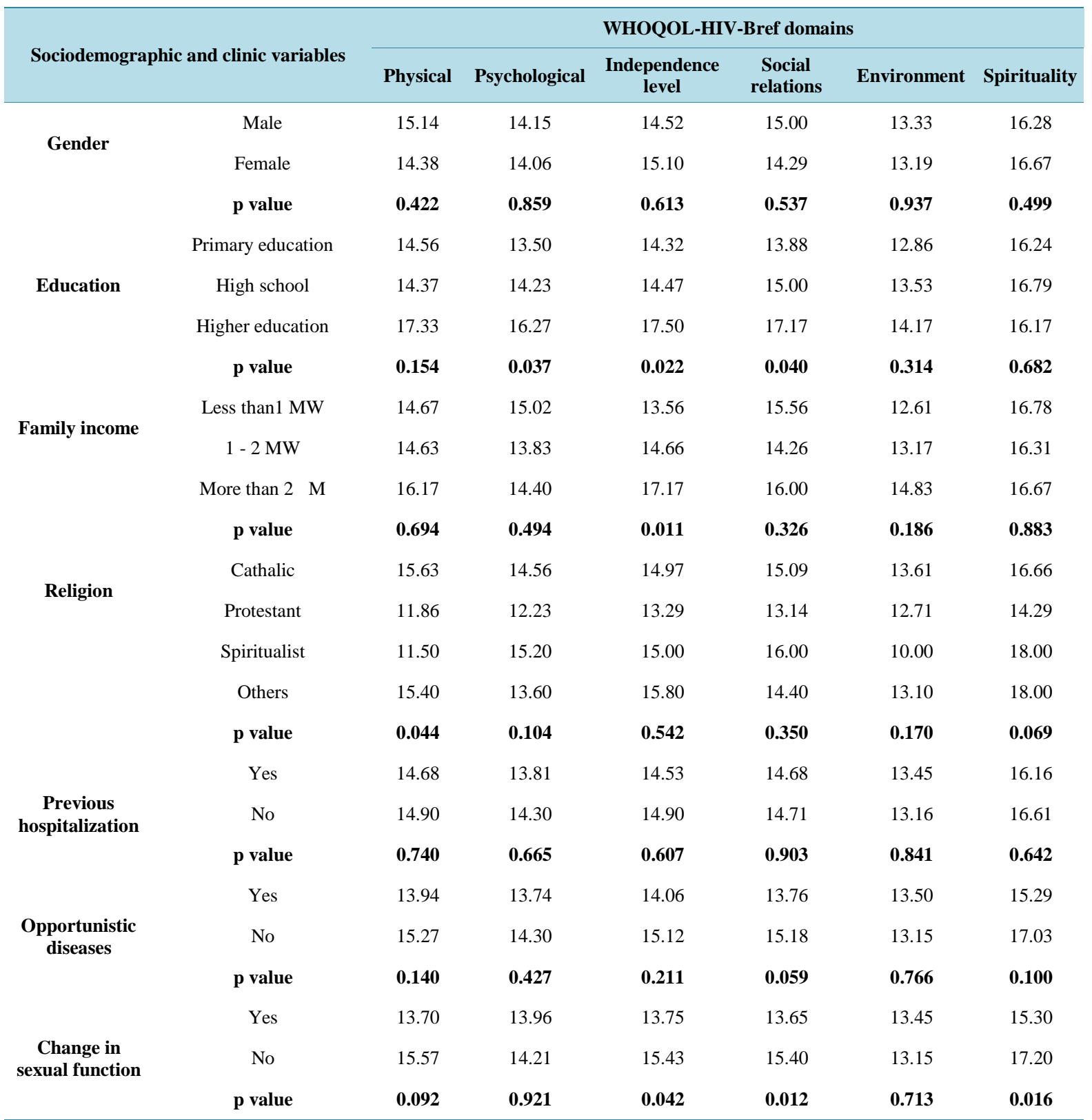

Although the feelings of anger and fear had the lowest scores in the QOL domains, these factors have a negative effect on coping, which can contribute to reducing the body's immune response and lead to the emergence of opportunistic diseases, bringing implications for the health of people living with HIV/AIDS [17].

Studies have shown that anger and fear are most evident during the phase of denial of the diagnosis of HIV/AIDS, as an attempt to psycho-emotional adaptation to the new reality. With acceptance of the diagnosis, treatment adherence and understanding by the family, as well as the social support, a positive change, of learning, valuing life and maturation starts to appear [18].

Accordingly, the domain spirituality/religious/personal beliefs also presented statistical association with feelings, especially joy, anxiety and security as a positive contribution to coping with the health-disease process, minimizing stress, as well as arousing feelings of resilience, well-being and survival of people living with HIV [15] [16].

The domains, psychological, level of independence and social relations had significant association with the 
variable education. Considering the low level of knowledge among the elderly as a risk factor for the increase of HIV infection in this age group, studies have shown that primary education is the level of education of the majority of the elderly, and the number of illiterates is still high among them [19]-[21].

Low access to information and ignorance of the ways of transmission and prevention of HIV makes them more vulnerable to the virus and facilitates the emergence of opportunistic diseases, mainly because of the difficulty and delay in diagnosis, which interferes drastically in the QOL [22].

Since education is an important marker of risk conditions and vulnerability of the population, the increase in the number of cases in the strata with higher education may refer to a bad coverage of surveillance and assistance systems among the poor people [19], since people with higher income have better health and therefore QOL [22].

In the domains level of independence, social relations and spirituality/religion/personal beliefs, it was observed correlation with the variable change in sexual and physiological function. In contrast to the results of this research, a study found that after the discovery of seropositivity, some patients reported decreased sexual desire and activity, mainly due to fear, because of the acquisition of HIV through sexual intercourse. The major impact generated on QOL hampers sexual satisfaction and social relationships, leading to decreased self-esteem and even the sexual isolation [19].

The decrease in sexual desire after acquiring HIV is also strongly linked to the need of condom use and fear of relating to the other, fear that the partner figures out about the HIV/AIDS, as well as the ignorance about the disease and forms of transmission [18] [23].

In people over 50 years old, these sexual behaviors generate several discussions regarding the use of the condom, since many patients report that condoms interfere with sexual and affective life by causing discomfort, fear of hampering the penile erection and lessen the feeling of pleasure [23].

It is noteworthy that condom use is essential for the survival of the HIV-positive person, as it prevents the transmission of the virus, reducing the infection rate and helps reducing the viral load and the risk of acquiring other STDs [1] [24].

Given the context, the QOL stands as a construct with important potential of contribution to the practice of individual and collective nursing and health care to this group, as well as for the design of public policies and prevention and health education programs aimed at individuals over 50 years of age. The need to promote an active listening to the customer regarding their own health is essential to inform and warn the elderly population about AIDS, discussing issues related to sexuality in the third age, aiming to break taboos and discuss the repercussions of prejudice [9].

\section{Conclusions}

In this study, the results revealed that people living with HIV/AIDS have low scores in QOL domains. When associated with sociodemographic and clinical aspects, it was observed that they had associations with QOL, especially in regard to education, income, religion, change in sexual function and feelings, being crucial to a positive or negative influence in the QOL. Moreover, the spiritual domain stood out with higher average and best performance of QOL, collaborating to coping, hope and resilience of HIV/AIDS.

The relevance of this study is emphasized with regard to the focus in patients aged 50 years or older, through the creation of multidisciplinary care policies, seeking to suppress the affected aspects of QOL related to HIV infection/AIDS. The type of study and the exiguous time assigned for data collection were the limitation of this research. Authors suggest that further studies are carried out in order to intervene in the QOL of those people who are experiencing the aging process.

It is hoped that this research makes it possible to implement actions that can improve the QOL of this population, contributing to a positive change in the epidemiological and sociodemographic panorama and also be basis for the realization of new scientific research in the academic community in general.

\section{Conflicts of Interest}

The author confirms that this article content has no conflict of interest.

\section{References}

[1] Bezerra, V.P., Nunes, T.B., Nogueira, J.A., Pedroza, A.P., Trigueiro, D.R.S. and Silva, D.M. (2014) Vulnerabilidade 
de idosos ao contágio pelo HIV no contexto de práticas preventivas. Revista de Enfermagem UFPE Online, 8, 22-29.

[2] World Health Organization (2005) Envelhecimento ativo: Uma política de saúde. Tradução de Suzana Gontijo. Organização Pan-Americana da Saúde, Brasília. http://bvsms.saude.gov.br/bvs/publicacoes/envelhecimento_ativo.pdf

[3] UNAIDS-Joint United Nations Programme on HIV/AIDS (2014) The Gap Report. http://www.unaids.org/en/media/unaids/contentassets/documents/Unaidspublication/2014/unaids_gap_report_en.pdf

[4] Ministério da Saúde. Departamento de DST, Aids e Hepatites Virais (2014) Boletim Epidemiológico HIV/AIDS. http://www.aids.gov.br/sites/default/files/anexos/publicacao/2014/56677/boletim_2014_1_pdf_60254.pdf

[5] International Association of Providers AIDS Care (2014) Older People and HIV. Aids Education and Training Center at the University of the New Mexico and the International Association of Providers of AIDS Care. http://www.aidsinfonet.org/fact sheets/view/616

[6] Silva, A.C.O., Reis, R.K., Nogueira, J.A. and Gir, E. (2014) Quality of Life, Clinical Characteristics and Treatment Adherence of People Living with HIV/AIDS. Revista Latino-Americana de Enfermagem, 22, 994-1000. http://dx.doi.org/10.1590/0104-1169.3534.2508

[7] Padoin, S.M., Paula, C.C., Zuge, S.S., Primeira, M.R., Santos, E.E. and Tolentino, L.C. (2011) Fatores associados à não adesão ao tratamento antirretroviral em adultos acima de 50 anos que têm HIV/Aids. Jornal Brasileiro de Doenças Sexualmente Transmissíveis, 23, 194-197. http://dx.doi.org/10.5533/2177-8264-201123408

[8] World Health Organization (1995) The World Health Organization Quality of Life Assessment (WHOQOL): Position Paper from the World Health Organization. Social Science and Medicine, 41, 403-409.

[9] Costa, T.L., Oliveira, D.C., Gomes, A.M.T. and Formozo, G.A. (2014) Quality of Life and People with AIDS: Relationship with Sociodemographic and Health Aspects. Revista Latino-Americana de Enfermagem, 22, 582-590. http://dx.doi.org/10.1590/0104-1169.3350.2455

[10] Perez, I.R., Baño, J.R., Ruz, M.A.L., Jimenez, A.A., Prados, M.C., Liaño, J.P., et al. (2005) Health Related Quality of Life of Patients with HIV: Impact of Sociodemographic, Clinical and Psychosocial Factors. Quality of Life Research, 14, 1301-1310. http://dx.doi.org/10.1007/s11136-004-4715-x

[11] Okuno, M.F.P., Gomes, A.C., Meazzini, L., Scherrer Junior, G., Belasco Junior, D. and Belasco, A.G.S. (2014) Qualidade de vida de pacientes idosos vivendo com HIV/AIDS. Cad Saúde Pública, 30, 1551-1559. http://dx.doi.org/10.1590/0102-311X00095613

[12] Ministério da saúde (2013) Sistema de Informação de Agravos de Notificação. Versão Online. http://www2.aids.gov.br/cgi/deftohtm.exe?tabnet/rn.def

[13] Zimpel, R.R. and Fleck, M.P. (2007) Quality of Life in HIV-Positive Brazilians: Application and Validation of the WHOQOL-HIV, Brazilian Version. AIDS Care, 19, 923-930. http://dx.doi.org/10.1080/09540120701213765

[14] Pereira, L.B., Albuquerque, J.R., Santos, J.M., Lima, F.L.A. and Saldanha, A.A.W. (2012) Fatores Sociodemográficos e Clínicos associados à TARV e à Contagem T-CD4. Revista Brasileira de Ciências da Saúde, 16, 149-160. http://dx.doi.org/10.4034/RBCS.2012.16.02.06

[15] Gaspar, J., Reis, R.K., Pereira, F.M.V., Neves, L.A.S., Castrighini, C.C. and Gir, E. (2011) Quality of Life in Women with HIV/Aids in a Municipality in the State of São Paulo. Revista Escola de Enfermagem USP, 45, 230-236. http://dx.doi.org/10.1590/S0080-62342011000100032

[16] Calvetti, P.U., Muller, M.C. and Nunes, M.L.T. (2008) Qualidade de vida e bem-estar espiritual em pessoas vivendo com HIV/AIDS. Psicologia em Estudo, 13, 523-530. http://dx.doi.org/10.1590/S1413-73722008000300013

[17] Medeiros, B., Silva, J. and Saldanha, A.A.W. (2013) Determinantes biopsicossociais que predizem qualidade de vida em pessoas que vivem com HIV/AIDS. Estudos de Psicologia, 18, 543-550. http://dx.doi.org/10.1590/S1413-294X2013000400001

[18] Carvalho, S.M. and Paes, G.O. (2011) A influência da estigmatização social em pessoas vivendo com HIV/AIDS. Caderno de Saúde Coletiva, 19, 157-163.

[19] Lopes, P.S.D., Silva, M.M.G., Torres, I.C. and Stadñik, C.M.B. (2011) Qualidade de vida dos pacientes HIV positivo com mais de 50 anos. Revista da AMRIGS, 55, 356-360.

[20] Bertoni, R.F., Bunn, K. and Traebert, J. (2010) Perfil demográfico e socioeconômico dos portadores de HIV/AIDS do Ambulatório de Controle de DST/AIDS de São José, SC. Arquivos Catarinenses de Medicina, 39, 75-79.

[21] Toledo, L.S.G., Maciel, E.L.N., Rodrigues, L.C.M., Tristão-Sá, R. and Fregona, G. (2010) Características e tendência da AIDS entre idosos no Estado do Espírito Santo. Revista da Sociedade Brasileira de Medicina Tropical, 43, $264-267$. http://dx.doi.org/10.1590/S0037-86822010000300010

[22] Silva, J., Saldanha, A.A.W. and Azevedo, R.L.W. (2010) Variáveis de impacto na qualidade de vida de pessoas acima de 50 anos HIV+. Psicologia: Reflexão e Crítica, 23, 56-63. http://dx.doi.org/10.1590/s0102-79722010000100008

[23] Arrais, A.R., Rufino, M.R.D., Pereira, K.C.S.A., Santos, F.L.S. and Chaves, P.R.S. (2014) Atividade sexual e 
HIV/Aids na terceira idade: A vivência de alunos da Universidade da Maturidade da Universidade Federal do Tocantins. Brasília Médica, 51, 4-12.

[24] Laroque, M.F., Affeldt, A.B., Cardoso, D.H., Souza, G.L., Santana, M.G. and Lange, C. (2011) Sexualidade do idoso: Comportamento para a prevenção de DST/AIDS. Revista Gaúcha de Enfermagem, 32, 774-780. 